\title{
Editing and modeling of milk production data for genetic evaluation of Murrah buffaloes
}

\author{
Andréa Carolina Santos de Souza( ${ }^{(1)}$, Marcos Paulo Gonçalves de Rezende(1), Paulo Luiz Souza \\ Carneiro $^{(2)}$, Bárbara Machado Campos ${ }^{(1)}$ and Carlos Henrique Mendes Malhado ${ }^{(2)}$
}

\begin{abstract}
(1)Universidade Estadual do Sudoeste da Bahia, Praça Primavera, no 40, Primavera, CEP 45700-000 Itapetinga, BA, Brazil. E-mail: dea.carolina@hotmail.com, mpgrezende@gmail.com, zoo.ufrb@yahoo.com.br (2)Universidade Estadual do Sudoeste da Bahia, Departamento de Ciências Biológicas, Avenida José Moreira Sobrinho, s/no-, Jequiezinho, CEP 45200-000 Jequié, BA, Brazil. E-mail plscarneiro@gmail.com, carlosmalhado@gmail.com
\end{abstract}

\begin{abstract}
The objective of this work was to assess the effect of editing and modeling of milk production data for genetic evaluation of Murrah buffaloes. Six strategies for evaluating milk production were analyzed: observed milk production (OMP); adjustment of milk production data to 305 (MP305) and 270 (MP270) days of lactation; removal of the 5 (MP5\%) and 10\% (MP10\%) shortest lactation periods; and milk production along the lactation period as linear covariate (MPCO). Genetic parameters were estimated using the Bayesian inference, with heritability estimates of 0.19 to 0.23 and repeatability estimates of 0.35 to 0.36 . Sires classified by OMP were high correlated to those classified by the other models, however, correlations to MP270, MP305 and MPCO decreased when considering only the best $20 \%$ sires. OMP showed greater differences in absolute mean deviations when compared with MPCO, MP270 and MP305. The strategies of analysis had similar heritabilities and stabilities. However, changes in the ranking of sires with better classifications, due to overestimation of genetic values, as occurred in the models MP305, MP270 and MPCO, may lead to a decrease in the genetic progress of the herd.
\end{abstract}

Index terms: Bubalus bubalis, lactation period, genetic parameters, bull summary.

\section{Edição e modelagem de dados de produção de leite para avaliação genética de buffalos de Murrah}

\begin{abstract}
Resumo - O objetivo deste trabalho foi verificar as consequências da edição e modelagem da produção de leite para avaliação genética de bubalinos da raça Murrah. Foram analisadas seis estratégias para avaliação da produção de leite: produção de leite observada (PL_OBS); ajuste para a produção de leite aos 305 dias (PL_305) e aos 270 dias (PL_270); exclusões dos 5 e 10\% menores períodos de lactação (PL_5\% e PL_10\%) e duração da lactação como covariável linear (PL CO). Os parâmetros genéticos foram estimados por meio de inferência Bayesiana, com estimativas de herdabilidades e repetibilidades de 0,19 a 0,23 e 0,35 a 0,36 , respectivamente. Touros classificados pelo PL_OBS apresentaram altas correlações com os que foram classificados pelos outros modelos. Contudo, ao considerar apenas os $20 \%$ melhores touros, verificou-se diminuição das correlações de PL_270, PL_305 e PL_CO com PL_OBS. Maiores diferenças dos desvios médios absolutos do PL_OBS foram com PL_CO, PL_270 e PL_305. As estratégias de análise apresentaram herdabilidades e estabilidade semelhantes. Contudo, as inversões de posições dos touros com melhores classificações, como consequencia das superestimativas dos valores genéticos nos modelos PL305, PL270 e PL_CO podem acarretar em diminuição do progresso genético nos rebanhos.
\end{abstract}

Termos para indexação: Bubalus bubalis, duração da lactação, parâmetros genéticos, sumário de touros.

\section{Introduction}

The number of buffaloes (Bubalus bubalis) have been increasing in the Brazilian livestock due to their rusticity, longevity, high adaptive capacity to adverse conditions (Joele et al., 2013; Barros et al., 2016; Santos et al., 2016) and resistance to diseases and endo and ectoparasites (Hurtago-Lugo et al., 2013).
These animals have double suitability (milk and meat) and for many years were reared as a secondary activity in Brazilian farms. However, dairy products from buffalo milk, such as yogurts, cheeses, ricotta and especially mozzarella, have reached high market values (Araújo et al., 2012; Barros et al., 2016). Therefore, the need for investments in sanitary, 
nutritional and genetic improvements has become necessary to increase productive and reproductive potentials of buffalo herds (Hurtago-Lugo et al., 2013; Ramos et al., 2013).

Murrah is the main buffalo genetic group for milk production in Brazil, which has average milk production of 1,496 to $2,130 \mathrm{~kg}$ per lactation (Marcondes, 2011; Tonhati et al., 2013). However, lactation periods of buffalo cows have large amplitude, varying from 150 to 301 days (Tonhati et al., 2007; Baldi et al., 2011; Marcondes, 2011; Malhado et al., 2013; Rangel et al., 2014), reinforcing the importance of assessing strategies for genetic evaluations of dairy buffaloes, improving predictions of genetic values of sires.

The adjustment of milk production data to 305 days of lactation is commonly used for genetic evaluations of Brazilian dairy cattle (Costa et al., 2012; Panetto et al., 2015; Silva et al., 2015). Only three genetic evaluation summaries of buffaloes were published in Brazil and in the first two, milk productions were adjusted to 270 and 305 days of lactation (Ramos, 2001; Ramos et al., 2004). This adjustment was also used by Rassi et al. (2009) and Malhado et al. (2007) to correlate partial and total milk production and estimate genetic parameters and trends, respectively. The adjustment of milk production data to 305 days of lactation was used in the third summary (ABCB, 2006). Other studies estimated genetic parameters and values in buffaloes using milk production as a covariate (Tonhati et al., 2007; Rodrigues et al., 2010; Baldi et al., 2011).

However, no studies assessing effects of editing and modeling of milk production for estimating genetic parameters and values of buffaloes are found in the literature. Moreover, several authors have reported the effect of data editing in genetic evaluations (Cardoso et al., 2009; Facó et al., 2009; Malhado et al., 2013).

The objective of this work was to assess the effect of editing and modeling of milk production data for genetic evaluation of Murrah buffaloes, to assist in genetic researches and evaluations.

\section{Material and Methods}

The experiment was performed in 2015 with lactation data of 2,952 buffalo cows of the Murrah breed from the Promebul Buffalo Breeding Program. Ten herds were evaluated, which were part of ten farms in the States of Bahia, São Paulo, Ceará, Pará,
Minas Gerais, Rio Grande do Norte and Paraná. The mean and standard deviation of total milk production and lactation period were $1649.99 \pm 659.54 \mathrm{~kg}$ and $271.34 \pm 46.59$ days, respectively.

Contemporary groups were divided by year of birth (21), calving season (May to July, August to October, November to January and February to April) and herd (10). The strategies proposed to evaluate milk production of buffalo cows were: observed milk production (OMP) without adjustment, used as comparative parameter to data with editing; adjustment of milk production data to 305 (MP305) and 270 (MP270) days of lactation, performed by interpolation; removal of the 5 (MP5\%) and 10\% (MP10\%) shortest lactation periods, delimited by quartiles at 5 (199 days) and $10 \%$ (217 days), i.e., exclusion of lactations shorter than $199(5 \%$, representing 152 animals) and $217(10 \%$, representing 302 animals) days; and milk production along the lactation period as linear covariate (MPCO).

The statistical model used to describe milk production was $\mathrm{Y}_{\mathrm{PL}}=\mathrm{X} \beta+\mathrm{Za}+\mathrm{Wpe}+\mathrm{e}$ wherein $\mathrm{Y}$ is the vector of observation of the variable dependent on milk production (OMP, MP305, MP270, MP5\%, MP10\% and MPCO); $\beta$ is the vector of fixed effects (contemporary groups, calving order and number of milking), $\beta_{\mathrm{MPCO}}$ is the covariant lactation period (linear) for the model MPCO, related to $\mathrm{Y}$ by the incidence matrix X; $a$ is the vector of random effect of additive genetic value of the animal, related to $Y$ by the incidence matrix $Z$; pe is the vector of random permanent environmental effects, related to $\mathrm{Y}$ by the incidence matrix $\mathrm{W}$; and $\mathrm{e}$ is the vector of random error effects.

The statistical models were determined and the densities of the variance components were obtained by samples generated by the Markov chain Monte Carlo (MCMC), using the Gibbs sampler in the program GIBBS3F90 (Misztal, 2012). Chains of 220,000 or 500,000 iterations were used, with discard (burn-in) of 20,000 or 50,000 samples and a rescue interval (thin) of 50 samples. The convergence diagnosis was performed following the Geweke method, using the BOA (Bayesiam Output Analysis) package of the $\mathrm{R}$ program (R Core Team, 2008).

The models were compared by using the Cross Validation technique, Akaike information criterion (AIC) and Bayesian information criterion (BIC). Spearman correlations between the bull classifications 
were performed to compared the estimates of genetic values of the models, using the seven models, in the $\mathrm{R}$ program. First, all sires were subjected to these analyzes, then only the best sires (20\%) with at least five progenies with milk production, and finally the eight best sires, which were used to calculate the differences of the absolute mean deviations (AMD) of the adjusted models in relation to OMP, using the model:

$$
\mathrm{AMD}=\frac{\sum_{\mathrm{i}=1}^{\mathrm{n}} \sqrt{(\hat{\mathrm{a} i}-\hat{\mathrm{a} j})^{2}}}{\mathrm{n}}
$$

where in âi is the genetic value estimated by OMP, âj is the genetic value estimated by the models (MP270, MP305, MP5\%, MP10\% and MPCO), and $n$ is the the sample size. The lower the estimated value of the AMD, the better the adjustment.

\section{Results and Discussion}

The correlation of the models through Cross Validation showed similar values for OMP (0.76), MP10\% (0.76), MPCO (0.76), MP305 (0.75), MP5\% (0.75) and MP270 (0.74). Thus, these models were similar, since close correlations denote similar stabilities (Urioste et al., 2007).

Lower values by the Akaike information criterion (AIC) and Bayesian information criterion (BIC) denote better fitting of the model for genetic evaluations (Aliloo et al., 2014). Thus, the best models were MP10\%, MP5\%, MP270, MPCO, MP305 and OMP (Table 1). However, the models MP5\% and MP10\% may have been favored by data exclusions with the quartiles values at 5 (lactation periods shorter than 199 days) and 10\% (lactation periods shorter than 217 days).

Discarding of information by data editing has been contested, since it may decrease genetic variability in population evaluations (Cunha \& Melo, 2012). Therefore, the exclusion of short lactations can bias estimates, affecting the actual variability of the characteristic and genetic differences between animals (Madalena et al., 1992). However, according to Facó et al. (2009) elimination of short lactations does not decrease genetic variability, but contribute to a substantial decrease of residual variance.

The heritability coefficients of the models ranged from 0.19 to 0.23 , denoting a small variation in the six models evaluated (Table 2). The models showed similar repeatability ( 0.35 to 0.36 ). According to the interval of credibility, the estimates of the models had no significant differences in heritability and repeatability.

The heritabilities of the models denote possibility of genetic gain for milk production through selection. These results confirm those reported in other studies that found heritabilities ranging from 0.20 to 0.25 (Malhado et al., 2007; Rodrigues et al., 2010; Tonhati et al., 2013). The repeatability of the models was low, preventing to predict future productions in the first lactations. Similar or higher estimates of repeatability were found by Ramos et al. (2013) (0.38) and Malhado et al. (2013) (0.50) in Murrah buffalos.

The heritabilities of the models MP270 (0.22) and MP305 (0.23) were similar to those found in the literature for buffaloes with adjustments for 270 days (Malhado et al., 2007; Rodrigues et al., 2010) and for 305 days (Aspilcueta-Borquis et al., 2010).

The lowest estimates of heritabilities of the models MP10\% (0.19) and MP5\% (0.20) were due to the exclusions of lactation data by genetic reasons. The variance due to permanent environmental effects decreased when excluding $10 \%$ of the short lactations, also denoting that environmental variations can permanently affect milk production of buffalo cows.

Baldi et al. (2011) evaluated milk production of Murrah buffaloes with exclusions of lactations shorter than 90 and 150 days and found higher variance of permanent effect when using exclusions. Madalena et al. (1992) recommended not to exclude short lactations, avoiding decreasing variance and biasing estimates,

Table 1. Average estimates by the Akaike Information Criterion (AIC) and Bayesian Information Criterion (BIC).

\begin{tabular}{lcc}
\hline Model $^{(1)}$ & AIC & BIC \\
\hline OMP & 44112.93 & 44154.85 \\
MP305 & 44006.70 & 44048.60 \\
MP270 & 43047.10 & 43089,00 \\
MP5\% & 41935.60 & 41977.20 \\
MP10\% & 39756.00 & 39797.20 \\
MPCO & 43448.10 & 43496.10 \\
\hline
\end{tabular}

(1) OMP, observed milk production; MP305, adjustment of milk production data to 305 ; MP270, adjustment of milk production data to 270 days; MP $5 \%$, removal of the $5 \%$ lower milk productions; MP $10 \%$, removal of the $10 \%$ lower milk productions; and MPCO, milk production along the lactation period as linear covariate. 
and indicated to exclude only results from abnormal productions, with errors in data collection and from cows with diseases.

The estimate of heritability of the model MPCO was 0.23 , similar to the MP305. Other authors found no decreased variability with this covariate, but a decreased heritability compared with models by multiplicative correction factors and adjusted to 270 and 305 days of lactation (Tonhati et al., 2007; Baldi et al., 2011).

Correlations of bull classification by OMP with those by the other models were high and significant (Table 3). This result denotes high maintenance of classification rankings in relation to OMP. However, correlations of OMP with MP305, MP270 and MPCO decreased when considered only the classification of the $20 \%$ best sires (Table 3 ). This result may lead to inappropriate choices of sires for breeding, especially due to the overestimation of genetic values by the models MP305, MP270 and MPCO. The models MP5\% and MP10\% had slightly increased correlations, which was expected, since the exclusion of the $5 \%$ or $10 \%$ shortest lactation periods can alter results of the worst sires, with little or no effect on the best sires.

Sires classified by OMP were similar to those classified by the other models for the two best sires (Table 4). The greatest variations in the classification were observed in the subsequent positions, especially in the models MPCO, MP305 and MP270, confirming the greater differences of the absolute mean deviations (AMD) of the eight best sires, with differences of 45.37 (MPCO), 48.62 (MP270), 34.75 (MP305), 31.50 (MP5\%) and 28.00 (MP10\%) in relation to OMP.

Considering the information of OMP, selection intensity of 1.38 (retention of $2 \%$ of males and $80 \%$ of

Table 2. Estimates of the covariance components, heritability, repeatability and descriptive analyzes of milk production of Murrah buffaloes through six statistical models.

\begin{tabular}{|c|c|c|c|c|c|c|c|}
\hline \multirow[t]{2}{*}{ Model $^{(1)}$} & \multirow{2}{*}{$\begin{array}{l}\text { Descriptive } \\
\text { analyzes }^{(2)}\end{array}$} & \multicolumn{6}{|c|}{ Parameter $^{(3)}$} \\
\hline & & $\sigma_{a}^{2}$ & $\sigma_{\mathrm{pe}}^{2}$ & $\sigma_{\mathrm{e}}^{2}$ & $\sigma_{\mathrm{p}}^{2}$ & Heritability $\left(\mathrm{h}^{2}\right)$ & Repeatability \\
\hline \multirow{4}{*}{ OMP } & Mean & 54813.81 & 39100.75 & 171405.84 & 265320.41 & 0.21 & 0.35 \\
\hline & CV (\%) & 23.24 & 26.25 & 3.36 & 3.35 & 21.26 & 6.73 \\
\hline & IC (95\%) & $30670-80050$ & $20080-60510$ & $160300-182700$ & $248470-283090$ & $0.12-0.29$ & $0.31-0.40$ \\
\hline & SE & 201.45 & 162.30 & 91.06 & 140.67 & 0.00071 & 0.00038 \\
\hline \multirow{4}{*}{ MP305 } & Mean & 57733.72 & 32286.86 & 164090.75 & 254111.33 & 0.23 & 0.35 \\
\hline & CV (\%) & 20.28 & 28.07 & 3.32 & 3.31 & 18.66 & 6.66 \\
\hline & IC (95\%) & $36450-81760$ & $15220-49780$ & $153200-174300$ & $204870-305840$ & $0.18-0.27$ & $0.25-0.43$ \\
\hline & SE & 185.11 & 143.28 & 86.03 & 132.81 & 0.00067 & 0.00037 \\
\hline \multirow{4}{*}{ MP270 } & Mean & 44846.73 & 27053.31 & 127952.15 & 199852.2 & 0.22 & 0.36 \\
\hline & CV (\%) & 21.29 & 27.47 & 3.36 & 3.36 & 19.57 & 6.51 \\
\hline & IC (95\%) & $27990-64540$ & $11930-40800$ & $120000-136100$ & $159920-241440$ & $0.18-0.27$ & $0.25-0.44$ \\
\hline & SE & 150.95 & 117.52 & 67.88 & 106.18 & 0.00069 & 0.00037 \\
\hline \multirow{4}{*}{ MP5\% } & Mean & 49541.07 & 42371.5 & 169239 & 261151.57 & 0.19 & 0.35 \\
\hline & CV (\%) & 26.43 & 25.36 & 3.42 & 3.4 & 24.84 & 6.82 \\
\hline & IC (95\%) & $24360-74800$ & $20190-62520$ & $158800-181400$ & $202250-318720$ & $0.12-0.23$ & $0.22-0.43$ \\
\hline & SE & 207.01 & 169.91 & 91.42 & 140.25 & 0.00074 & 0.00038 \\
\hline \multirow{4}{*}{ MP10\% } & Mean & 52969.21 & 41219.78 & 169064.67 & 263253.67 & 0.20 & 0.36 \\
\hline & CV (\%) & 26.19 & 27.28 & 3.66 & 3.56 & 24.54 & 7.02 \\
\hline & IC (95\%) & $25770-79960$ & $19860-63080$ & $156900-80800$ & $202530-265370$ & $0.13-0.30$ & $0.23-0.46$ \\
\hline & SE & 219.31 & 177.78 & 97.72 & 148.34 & 0.00078 & 0.0004 \\
\hline \multirow{4}{*}{ MPCO } & Mean & 48533.78 & 27930.28 & 133914.7 & 210378.76 & 0.23 & 0.36 \\
\hline & CV (\%) & 20.92 & 28.21 & 3.29 & 3.36 & 19.18 & 6.35 \\
\hline & IC (95\%) & $28670-68050$ & $12530-43010$ & $125500-142400$ & $166700-253460$ & $0.17-0.27$ & $0.25-0.44$ \\
\hline & SE & 160.55 & 124.59 & 69.63 & 111.7 & 0.0007 & 0.00036 \\
\hline
\end{tabular}

${ }^{(1)} \mathrm{OMP}$, observed milk production; MP305, adjustment of milk production data to 305; MP270, adjustment of milk production data to 270 days; MP5\%, removal of the $5 \%$ lower milk productions; MP10\%, removal of the $10 \%$ lower milk productions; and MPCO, milk production along the lactation period as linear covariate. ${ }^{(2)} \mathrm{IC}$, interval of credibility at $95 \%$ for the components of variance; and SE, standard error. ${ }^{(3)} \sigma_{\mathrm{a}}^{2}$, additive genetic variance; $\sigma_{\mathrm{pe}}^{2}$, permanent environmental variance; $\sigma_{e}^{2}$, residual variance; $\sigma^{2}$, phenotypic variance. 
females), heritability of 0.21 and phenotypic standard deviation of $682.4 \mathrm{~kg}$, the annual genetic gains would be $198 \mathrm{~kg}$ per generation. However, despite the small differences in genetic values $(\mathrm{GV})$ and classifications of sires by the models, differences were apparent due to the use of breeding sires. For example, the selection of the bull $2188(\mathrm{GV}=243 \mathrm{~kg})$ as the third best bull by the models MP270, MP305 and MPCO, instead of the bull $3648(\mathrm{GV}=309 \mathrm{~kg})$, which was classified as third best by OMP, would lead to a difference of $33 \mathrm{~kg}(16.66 \%$ of $198 \mathrm{~kg})$ in the GV of the progeny, which would be an effect of the overestimated GV of the bull 2188 by the models MP270, MP305 and MPCO.

These results confirm those found by Facó et al. (2009), who reported that the adjustment of milk production data considering lactation periods leads to erroneous conclusions in comparing genetic groups of Dutch and Gir dairy cattle and in classifying animals by genetic merit. According to these authors, the removal of short lactation periods was an adequate decision to improve quality of genetic evaluations.

Table 3. Spearman correlation between classifications of all Murrah sires, and Spearman correlation between classifications of the $20 \%$ best Murrah sires, with at least five progenies under lactation ${ }^{(1)}$.

\begin{tabular}{lccccc}
\hline Model $^{(2)}$ & MP305 & MP270 & MP5\% & MP10\% & MPCO \\
\hline OMP & $0.93^{* * *}$ & $0.93^{* * *}$ & $0.96^{* * *}$ & $0.92^{* * *}$ & $0.93 * * *$ \\
OMP 20\% & $0.80^{*}$ & $0.86^{* *}$ & $0.98^{* * *}$ & $0.93^{* * *}$ & $0.87^{* *}$ \\
\hline
\end{tabular}

(1)MP305, adjustment of milk production data to 305 ; MP270, adjustment of milk production data to 270 days; MP5\%, removal of the $5 \%$ lower milk productions; MP10\%, removal of the 10\% lower milk productions; and MPCO, milk production along the lactation period as linear covariate. ${ }^{(2)} \mathrm{OMP}$, observed milk production; OMP $20 \%$, observed milk production considering the $20 \%$ best sires of the breed. ***, *** and *Significantly at $0.1,1$, and $5 \%$ probability, respectively.

Table 4. Genetic values and classifications of the eight best Murrah buffalo sires (in parentheses) with at least ten progenies under lactation, using six statistical models ${ }^{(1)}$.

\begin{tabular}{lccccccccc}
\hline Bull & OMP & MP305 & MP270 & MP5\% & MP10\% & MPCO & LP & GV \\
\hline \multirow{2}{*}{3227} & 571 & 579 & 519 & 532 & 545 & 532 & 281.15 & 546.33 & 2334.48 \\
& $(1)$ & $(1)$ & $(1)$ & $(1)$ & $(1)$ & $(1)$ & \pm 40.59 & \pm 23.81 & \pm 594.50 \\
958 & 395 & 386 & 332 & 360 & 369 & 354 & 292.73 & 366 & 2118.03 \\
& $(2)$ & $(2)$ & $(2)$ & $(2)$ & $(2)$ & $(2)$ & \pm 36.10 & \pm 22.74 & \pm 1004.80 \\
3648 & 309 & 282 & 248 & 250 & 266 & 274 & 289.81 & 271.5 & 2130.02 \\
& $(3)$ & $(5)$ & $(5)$ & $(3)$ & $(3)$ & $(4)$ & \pm 42.54 & \pm 22.6 & \pm 721.54 \\
2188 & 243 & 300 & 315 & 232 & 265 & 314 & 260.04 & 278.16 & 1571.25 \\
& $(4)$ & $(3)$ & $(3)$ & $(4)$ & $(5)$ & $(3)$ & \pm 49.61 & \pm 36.49 & \pm 612.48 \\
876 & 237 & 321 & 286 & 208 & 218 & 270 & 244.18 & 256.66 & 1415.87 \\
& $(5)$ & $(4)$ & $(4)$ & $(6)$ & $(6)$ & $(5)$ & \pm 38.62 & \pm 43.42 & \pm 303.66 \\
3649 & 195 & 246 & 216 & 217 & 266 & 234 & 247.50 & 229 \\
& $(6)$ & $(6)$ & $(6)$ & $(5)$ & $(4)$ & $(6)$ & \pm 39.95 & \pm 25.1 & \pm 883.72 \\
2327 & 172 & 152 & 141 & 150 & 172 & 117 & 286.27 & 150.66 & 2038.93 \\
& $(7)$ & $(11)$ & $(9)$ & $(7)$ & $(8)$ & $(11)$ & \pm 48.20 & \pm 20.68 & \pm 663.37 \\
950 & 150 & 128 & 110 & 115 & 133 & 100 & 243.61 & 122.66 & 1725.25 \\
& $(8)$ & $(16)$ & $(15)$ & $(10)$ & $(10)$ & $(18)$ & \pm 36.14 & \pm 17.97 & \pm 248.66 \\
\hline
\end{tabular}

(1) OMP, observed milk production; MP305, adjustment of milk production data to 305; MP270, adjustment of milk production data to 270 days; MP5\%, removal of the $5 \%$ lower milk productions; MP10\%, removal of the $10 \%$ lower milk productions; and MPCO, milk production along the lactation period as linear covariate. LP, mean and standard deviation of lactation period; GV, mean and standard deviation of genetic value; and MP, mean and standard deviation of milk production. 


\section{Conclusions}

1. The genetic parameters found with the different strategies of data editing and modeling used are similar.

2. Significant changes in the genetic values of the Murrah buffaloes due to the data editing and modeling cause significant changes in the classification of the best sires, since the genetic values are overestimated or underestimated, which can lead to an inappropriate choice of breeding sires, compromising the genetic progress.

\section{Acknowledgments}

To Dr. Alcides Ramos Amorim (in memoriam), for his invaluable contribution to the Brazilian buffalo and animal production.

\section{References}

ABCB. Associação Brasileira de Criadores de Búfalos. Avaliação genética de búfalos leiteiros. 2007. Available at: $<$ http://www.bufalo. com.br/adobe/melhoram_2006.pdf>. Accessed on: June 162016.

ALILOO, H.; MIRAIE-ASHTIANI, S.R.; MORADI SHAHRBABAK, M.; URIOSTE, J.I.; SADEGHI, M. Accounting for heterogeneity of phenotypic variance in Iranian Holstein testday milk yield records. Livestock Science, v.167, p.25-32, 2014. DOI: 10.1016/j.livsci.2014.05.012.

ARAÚJO, K.B.S.; RANGEL, A.H.N.; FONSECA, F.C.E.; AGUIAR, E.M.; SIMPLÍCIO, A.A.; NOVAES, L.P.; LIMA JÚNIOR, D.M. Influence of the year and calving season on production, composition and mozzarella cheese yield of water buffalo in the State of Rio Grande do Norte, Brazil. Italian Journal of Animal Science, v.11, p.87-91, 2012. DOI: 10.4081/ ijas.2012.e16.

ASPILCUETA-BORQUIS, R.R.; DI PALO, R.; ARAÚJO NETO, F.R.; BALDI, F.; CAMARGO, G.M.F. de; ALBURQUERQUE, L.G. de; ZICARELLI, L.; TONHATI, H. Genetic parameter estimates for buffalo milk yield, milk quality and mozzarella production and Bayesian inference analysis of their relationships. Genetics and Molecular Research, v.9, p.1636-1644, 2010. DOI: 10.4238/vol9-3gmr846.

BALDI, F.; LAUREANO, M.M.M.; GORDO, D.G.M.; BIGNARDI, A.B.; ASPILCUETA BORQUIS, R.R.; ALBUQUERQUE, L.G. de; TONHATI, H. Effect of lactation length adjustment procedures on genetic parameter estimates for buffalo milk yield. Genetics and Molecular Biology, v.34, p.6267, 2011. DOI: 10.1590/S1415-47572011000100012.

BARROS, C. da C.; ASPILCUETA-BORQUIS, R.R.; FRAGA, A.B.; TONHATI, H. Genetic parameter estimates for production and reproduction traits in dairy buffaloes. Revista Caatinga, v.29, p.216-221, 2016. DOI: 10.1590/1983-21252016v29n125rc.
CARDOSO, F.F.; ROSA, G.J. de M.; TEMPELMAN, R.J.; TORRES JUNIOR, R.A. de A. Modelos hierárquicos bayesianos para estimação robusta e análise de dados censurados em melhoramento animal. Revista Brasileira de Zootecnia, v.38, p.72-80, 2009. Suplemento Especial. DOI: 10.1590/S151635982009001300009 .

COSTA, C.N.; COBUCI, J.A.; MARQUES, A.; RIBAS NETO, P.G.; VALLOTO, A.A.; HORST, J.A.; MENDONÇA JUNIOR, C.F. de; OLIVEIRA, F.O.F.; BRUNELI, F.A.T.; PANETTO, J.C. do C.; CAMPOS, L. de S.; RIGON, J.L.; PEREIRA, V.H.M.; SILVA, M.V.G.B.; MARTINS, M.F.; FREITAS, A.F. de. (Ed.). Sumário Nacional de Touros da Raça Holandesa. Juiz de Fora: Embrapa Gado de Leite, 2012. 40p. (Embrapa Gado de Leite. Documentos, 158). Available at: <http://ainfo.cnptia.embrapa. br/digital/bitstream/item/90335/1/DOC-158-Completo-TourosHoland-2012.pdf $>$. Accessed on: June 162016.

CUNHA, E.E.; MELO, T.P. de. Análise de sobrevivência nãoparamétrica da idade ao primeiro parto em fêmeas nelore: um estudo de simulação. Revista Brasileira de Biometria, v.30, p.305-325, 2012.

FACÓ, O.; MARTINS FILHO, R.; LOBO, R.N.B.; AZEVEDO, D.M.M.R.; OLIVEIRA, S.M.P. de. Efeito da redução da variação da duração de lactação na avaliação genética de bovinos leiteiros mestiços. Revista Ciência Agronômica, v.40, p.287-292, 2009.

HURTAGO-LUGO, N.A.; SOUSA, S.C. de; ASPILCUETA, R.R.; GUTIÉRREZ, S.Y.; CERÓN-MUÑOZ, M.F.; TONHATI, H. Estimation of genetic parameters for test-day milk yield in first calving buffaloes. Revista Colombiana de Ciencias Pecuarias, v.26, p.177-185, 2013.

JOELE, M.R.S.P.; LOURENÇO JUNIOR, J. de B.; FATURI, C.; GARCIA, A.R.; NAHÚM, B.S.; LOURENÇO, L.F.H.; OLIVEIRA, K.C.C. Sistemas silvipastoril e tradicional na Amazônia Oriental - produção e qualidade da carcaça e carne de búfalos. Semina: Ciências Agrárias, v.34, p.2457-2464, 2013. DOI: $10.5433 / 1679-0359.2013 v 34 n 5 p 2457$.

MADALENA, F.E.; LEMOS, A. de M.; TEODORO, R.L. Consequences of removing the variation in lactation length on the evaluation of dairy cattle breeds and crosses. Revista Brasileira de Genética, v.15, p.585-593, 1992.

MALHADO, C.H.M.; MALHADO, A.C.M.; RAMOS, A. de A.; CARNEIRO, P.L.S.; SOUZA J.C. de; PALA, A. Thailand. Genetic parameters for milk yield, lactation length and calving intervals of Murrah buffaloes from Brazil. Revista Brasileira de Zootecnia, v.32, p.565-569, 2013.

MALHADO, C.H.M.; RAMOS, A. de A.; CARNEIRO, P.L.S.; SOUZA, J.C. de; PICCININ, A. Parâmetros e tendências da produção de leite em bubalinos da raça Murrah no Brasil. Revista Brasileira de Zootecnia, v.36, p.376-379, 2007. DOI: 10.1590/ S1516-35982007000200014.

MARCONDES, C.R. Melhoramento de búfalos no Brasil: avanços, entraves e perspectivas. Revista Brasileira de Zootecnia, v.40, p.307-315, 2011. Suplemento especial.

MISZTAL, I. Fortran Programs. 2012. Available at: $<$ http://nce. ads.uga.edu/wiki/doku.php?id $=$ readme.gibbs3 $>$. Accessed on: July 132013. 
PANETTO, J.C. do C.; VERNEQUE, R. da S.; PEIXOTO, M.G.C.D.; BRUNELI, F.A.T.; MACHADO, M.A.; MARTINS, M.F.; SILVA, M.V.G.B. da; ARBEX, W.A.; REIS, D.R. de L.; GERALDO, C.C.; MACHADO, C.H.C.; PEREIRA, M.A.; HORTOLANI, B.; VERCESI FILHO, A.E.; MACIEL, R. da S.; FERNANDES, A.R. (Ed.) Programa Nacional de Melhoramento do Gir Leiteiro: Sumário Brasileiro de Touros: resultado do teste de progênie: $6^{\mathrm{a}}$ prova de pré-seleção de touros: maio 2015. Juiz de Fora: Embrapa Gado de Leite, 2015. 82p. (Embrapa Gado de Leite. Documentos, 177). Available at: <http://pt.slideshare.net/ ruralpecuariapecuaria/sumrio-gir-leiteiro-2015>. Accessed on: June 162016.

R CORE TEAM. R: a language and environment for statistical computing. Version 3.1.0. Vienna: R Foundation for Statistical Computing, 2008. Available at: <http://www.R-project.org>. Accessed on: May 232013.

RAMOS, A. de A. (Coord.). Promebul: Programa de Melhoramento Genético dos Bubalinos: sumário de touros bubalinos. Botucatu: Unesp, FMVZ, 2001. (Promebul. Boletim técnico, $\mathrm{n}^{\mathrm{o}}$ 1). Available at: <http://www.fmvz.unesp.br/bufalos/ HPBufalos_files/promebul/SUMARIO_2002.pdf $>$. Accessed on: June 152016.

RAMOS, A. de A.; WECHSLER, F.S.; VAN ONSELEN, V.J.; GONÇAlVES, H.C. (Coord.). Promebul: Programa de Melhoramento Genético dos Bubalinos: sumário de touros bubalinos. Botucatu: Unesp, FMVZ, 2004. (Promebul. Boletim técnico, $\mathrm{n}^{\mathrm{o}} 2$ ). Available at: <http://www.fmvz.unesp.br/bufalos/ HPBufalos_files/promebul/SUMARIO_2004.pdf >. Accessed on: June 152016.

RAMOS, A.A.; MALHADO, C.H.M.; MALHADO, A.C.M.; CARNEIRO, P.L.S.; SOUZA, J.C.; PALA, A. Productive and reproductive traits in Murrah breed from Brazil. Buffalo Bulletin, v.32, p.654-657, 2013. Special issue 2.

RANGEL, A.H. do N.; OLIVEIRA, J.P.F. de; MEDEIROS, H.R. de; ARAÚJO, V.M. de; NOVAES, L.P; LIMA JÚNIOR, D.M. de. Influence of Murrah buffalo behavior in milking parlors on production characteristics. Archives of Veterinary Science, v.19, p.53-61, 2014. DOI: 10.5380/avs.v19i3.34304.

RASSI, L.F.; ARAUJO, V.C.; VASCONCELlOS, B. de F. e; NASCENTE, F.X.; SCHWABACHER, V.G.; MOREIRA, P.C.
Correlação entre produções parciais e totais de leite em um rebanho bubalino. Estudos, v.36, p.1135-1139, 2009.

RODRIGUES, A.E.; MARQUES, J.R.F.; ARAÚJO, C.V.; CAMARGO JÚNIOR, R.N.C.; DIAS, L.N.S. Estimação de parâmetros genéticos para características produtivas em búfalos na Amazônia Oriental. Arquivo Brasileiro de Medicina Veterinária Zootecnia, v.62, p.712-717, 2010. DOI: 10.1590/ S0102-09352010000300028.

SANTOS, C.L.R. dos; SANTOS JÚNIOR, J.B. dos; CUNHA, M.C. da; NUNES, S.R.F.; BEZERRA, D.C.; TORRES JÚNIOR, J.R. de S.; CHAVES, N.P. Nível tecnológico e organizacional da cadeia produtiva da bubalinocultura de corte no estado do Maranhão. Arquivo do Instituto Biológico, v.83, p.1-8, 2016. DOI: $10.1590 / 1808-1657000022014$.

SILVA, M.V.G.B.; MARTINS, M.F.; PAIVA, L. de C.; CEMBRANELLI, M. de A.R.; ARBEX, W.A.; SANTOS, K.C.L. dos; PANETTO, J.C. do C.; CARVALHO, B.C. de; ALVES, B.R.C. Programa de melhoramento genético da raça Girolando: sumário de touros - resultado do teste de progênie - 3a prova de pré-seleção de touros: julho/2015. Juiz de Fora: Embrapa Gado de Leite, 2015. 73p. (Embrapa Gado de Leite. Documentos, 179). Available at: <http://ainfo.cnptia.embrapa.br/digital/bitstream/ item/129870/1/DOC-179-Sumario-de-Touros-Girolando-2015. pdf $>$. Accessed on: June 162016.

TONHATI, H.; ASPILCUETA-BORQUIS, R.R.; FREITAS, A.C. de; DE CAMARGO, G.M.F.; BALDI, F. Multiple-trait genomic evaluation for milk yield and milk quality traits using genomic and phenotypic data in buffalo in Brazil. Buffalo Bulletin, v.32, p.746-749, 2013. Special Issue 2.

TONHATI, H.; BALDI, F.S.; LAUREANO, M.M.M.; ALBUQUERQUE, L.G. Genetic parameters for milk yield of Bubalus bubalis using unadjusted and adjusted milk production for days in milk. Italian Journal of Animal Science, v.6, p.310313, 2007. Supplement. 2. DOI: 10.4081/ijas.2007.s2.310.

URIOSTE, J.I.; MISZTAL, I.; BERTRAND, J.K. Fertility traits in spring-calving Aberdeen Angus cattle. 2. Model comparison. Jornal Animal Science, v.85, p.2861-2865, 2007. DOI: 10.2527/ jas.2006-550.

Received on July 4, 2016 and accepted on May 18, 2017 